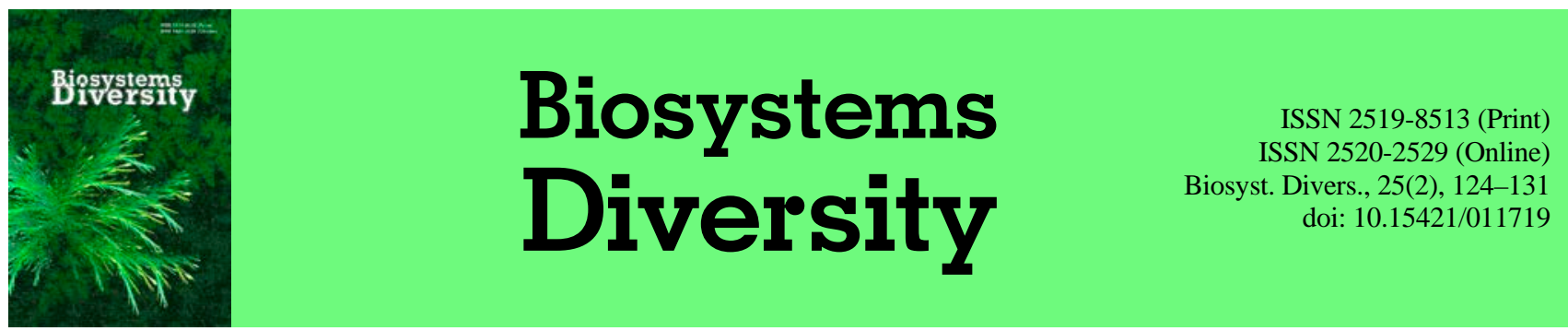

\title{
The temporal dynamics of zooplankton communities of different types of water bodies within Ichniansky National Park
}

\author{
Z. V. Burian, V. M. Trokhymets \\ Taras Shevchenko Kyiv National University, Kyiv, Ukraine
}

Article info

Received 19.04.2017

Received in revised form 09.05.2017

Accepted 12.05.2017

Taras Shevchenko Kyiv National University, Volodymyrska Str., 64, Kyiv, Ukraine

Tel.: +38-097-679-17-94.

E-mail: ke7sha1991@gmail.com
Burian, Z. V., \& Trokhymets, V. M. (2017). The temporal dynamics of zooplankton communities of different types of water bodies within Ichniansky National Park. Biosystems Diversity, 25(2), 124-131. doi:10.15421/011719

In recent decades, the influence of anthropogenic impact on aquatic ecosystems has increased. This has led to a restructuring of aquatic ecosystems and affected the structural and functional organization of groups of aquatic organisms, causing qualitative and quantitative changes. Particular attention is drawn to the different types of water bodies of protected areas like Ichnyansky National Park, which is located in Ichnyansky district of Chernihiv region. This park is a newly created one, so the reduction in intensity of anthropogenic pressure can be traced within its waters. Zooplankton plays an important role in the functioning of trophic networks because it transfers energy from producers and primary consumers to young fish and planktonophagous fish. Therefore, three main groups of zooplankton were chosen as the object of study: rotifers (class Eurotatoria), cladocerans (class Branchiopoda, order Cladocera), different age stages of copepods (class Copepoda), and also ostracods (Class Ostracoda). The zooplankton used as research material was collected in the daytime in spring (April), summer (late July - early August) and autumn (late September early October) in the years 2015-2016 from ten experimental stations. During this period 81 species of zooplankton were recorded within heterogeneous reservoirs of Ichniansky National Park. Monogonont rotifers (subclass Monogononta) included 35 species (43\% of all species) and bdelloid rotifers (subclass Bdelloidea), cladocerns, comprised 28 species (35\%), and copepods included 18 species (22\%). The faunal range of zooplankton over different years and seasons was characterized by the predominance of the rotator complex in spring, rotator-cladocerans and cladocerans in summer, and of the cladocerans complex in autumn. This was due to the formation during spring and summer of favourable conditions in the waters for filter feeders, which consist generally of rotifers and cladocerans. In autumn the water released large amounts of organic matter that caused a reduction in the species diversity of rotifers. Zooplankton also is characterized by the considerable ecological diversity. The range of environmental groups of zooplankton over two years was characterized by a predominance of the pelagic and benthic group of phytophiles. Pelagic representatives included 35 (43\%) of 81 species, the bottom group - 20 (25\%), phytophiles - 26 (32\%). Rotifers dominated in the pelagic group - 18 (51\%) species out of 35, and cladocerans - among the bottom group - 10 (50\%) species out of 20. Zooplankton species also are distinguished by their feeding type. They represented three trophic groups: peaceful - 64 (79\%) out of 81 species, omnivorous - 6 (7\%) and predators - 11 (14\%). Quantitative indicators of zooplankton at most stations in different seasons were defined as "very low" (less than 5,000 ind./ $\mathrm{m}^{3}$ and less than $\left.0.3 \mathrm{~g} / \mathrm{m}^{3}\right)$, "low" (5,000-50,000 ind. $/ \mathrm{m}^{3}$ and $\left.0.3-1.0 \mathrm{~g} / \mathrm{m}^{3}\right)$, "below average" (5,000-50,000 ind. $/ \mathrm{m}^{3}$ and $\left.0.3-1.0 \mathrm{~g} / \mathrm{m}^{3}\right)$

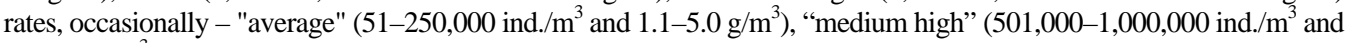
$1.1-5.0 \mathrm{~g} / \mathrm{m}^{3}$ ). High densities of zooplankton densities were recorded in spring for a temporary reservoir and amounted to $3,016,000$ ind. $/ \mathrm{m}^{3}$.

Keywords: zooplankton; protected area; Ukraine

\section{Часова динаміка угруповань зоопланктону різнотипних водойм Ічнянського національного природного парку}

\author{
3. В. Бур'ян, В. М. Трохимець
}

Київський національний університет імені Тараса Шевченка, Київ, Украӥна

Уперше проведено гідробіологічні дослідження на території Ічнянського національного природного парку. Представлено результати аналізу міжрічної та сезонної динаміки зоопланктону різнотипних водойм за 2015-2016 роки. Встановлено видове багатство зоопланктону в межах 10 дослідних станцій, яке представлене 81 видом коловерток, гіллястовусих і веслоногих ракоподібних. За фауністичним спектром угруповання зоопланктону за два роки переважали представники ротаторно-кладоцерного комплексу. Розраховано індекс Жаккара для визначення подібності видового складу зоопланктону, який підтвердив невисоку подібність видового багатства між 2015 та 2016 роками J 45,7\%. Проаналізовано основні екологічні показники угруповань зоопланктону: екологічний спектр, трофічний спектр, щільність та біомасу. Найвищі показники щільності характерні для весняного угруповання зоопланктону (3 016000 екз./ $\left.{ }^{3}\right)$ тимчасової водойми.

Ключові слова: зоопланктон; природоохоронна територія; Україна 


\section{Вступ}

Протягом останніх десятиліть у багатьох країнах спостерігається зростання антропогенного навантаження на водні екосистеми. Це зумовлює перебудови водних екосистем і впливає на структуру угруповань гідробіонтів (Baranyi et al., 2002; Booker and Cheruvelil, 2011; Gophe, 2015), викликаючи їх якісні та кількісні зміни (Clarke and Bennett, 2003; Segers, 2008; Nazaruk and Khamar, 2011). Із кожним десятиліттям в Україні зростає кількість річок із докорінно зміненим режимом (Bobyliov et al., 2014). Разом зі зміною гідрографії річкової мережі змінюється рельєф прилеглих територій. Особливу увагу привертають різнотипні водойми природоохоронних територій (Dulić, 2006; Larson et al., 2008; Guevara et al., 2010; Uttah et al., 2010; Pandey and Upadhyay, 2015), подібні до Ічнянського національного природного парку (НПП), створений у 2004 році в межах Ічнянського району Чернігівської області. Оскільки даний об'єкт природно-заповідного фонду створений нещодавно, то дослідження гідробіонтів його водойм дають можливість проаналізувати динаміку змін антропогенного навантаження (Sollberger et al., 1992; Xu et al., 2001; Soto and Rios, 2006; Chalkia and Kehayias, 2013; Pashkova, 2013).

Зоопланктон відіграє важливу роль у функціонуванні трофічних мереж, оскільки передає енергію від продуцентів і консументів першого порядку до молоді риб та риб-планктофагів (Havel and Shurin, 2004; Meerhoff et al., 2007; Forró et al., 2008; De los Ríos-Escalante, 2010; Trokhymets et al., 2011; Czerniawski and Domagał, 2013). Раніше досліджень щодо зоопланктону водойм Ічнянського НПП не проводили, тому мета дослідження - визначення видового багатства й екологічних особливостей угруповань зоопланктону різнотипних водойм у контексті в контексті сезонної та міжрічної динаміки.

\section{Матеріал і методи}

Об'єкт досліджень - три основні групи зоопланктону: коловертки (клас Eurotatoria), гіллястовусі ракоподібні (клас Branchiopoda, ряд Cladocera), різні вікові стадії розвитку веслоногих ракоподібних (клас Сорероda), черепашкові ракоподібні (клас Ostracoda). Моногононтних коловерток, гіллястовусих і веслоногих ракоподібних визначали до виду, а бделоїдних коловерток (підклас Bdelloidea) та черепашкових ракоподібних до вищих таксономічних груп надвидового рангу. Матеріалом дослідження послужив зоопланктон, зібраний у світлу пору доби навесні $(15,28$ квітня), влітку (28-30 липня, 1-2 серпня) та восени (30 вересня, 16 жовтня) 2015-2016 років у межах десяти дослідних станцій різнотипних водойм (рис. 1): річка Іченька - N 5047.783’ E 32¹6.095'; N 5046.129’ Е 32¹4.679';

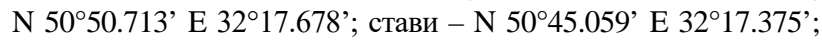

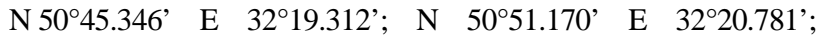
N 5046.583' Е $32^{\circ} 20.408^{\prime}$; болота - N 5045.548' Е 32 $18.921^{\prime}$; N 5051.316' Е 32²0.701', тимчасова водойма - N 5047.049' E $32^{\circ} 15.936$ '. Досліджували зоопланктон у межах різних біотопів: зарослого - у формаціях очерету звичайного, рогозу широколистого, глечиків жовтих, ряски малої, латаття білого, стрілолисту звичайного, та на чистоводі. Зоопланктон збирали шляхом фільтрації через конічну планктонну сітку. Всього зібрали та проаналізували на основі загальноприйнятих методик 74 проби зоопланктону (Zhadin, 1960; Manujlova, 1964; Pesenko, 1982; Berezina, 1989; Martin and Davis, 2001; Monchenko, 2003; Arsan et al., 2006). Провели порівняльний аналіз видового багатства, екологічного та трофічного спектру, кількісних показників різнотипних водойм Ічнянського НПП із найближчою великою штучною водоймою - Київським водосховищем.

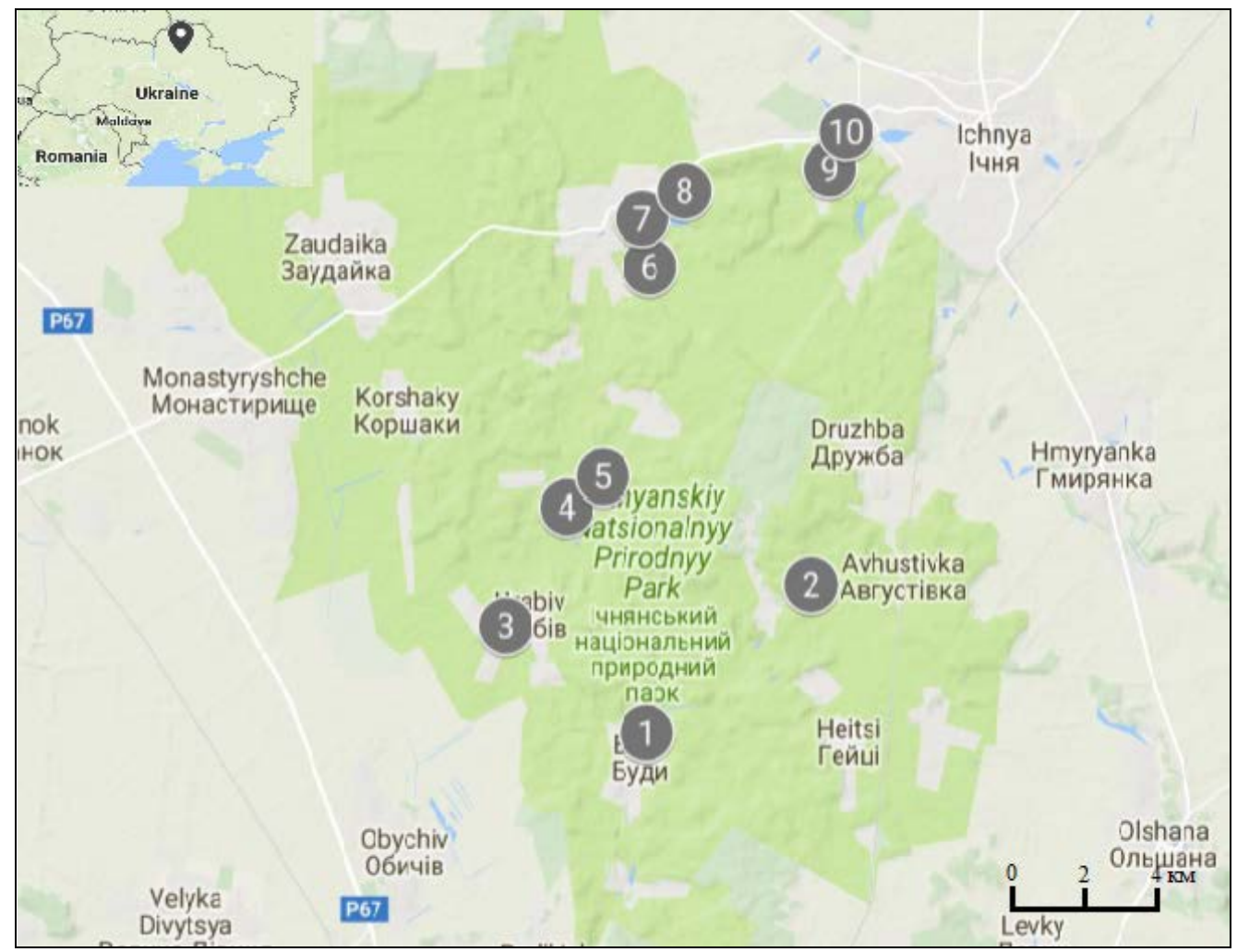

Рис. 1. Станції відбору проб зоопланктону різнотипних водойм у межах Ічнянського національного природного парку:

3,5, 8 - річка Іченька, 1, 2, 7,9 - стави, 6, 10 - болота, 4 - тимчасова водойма

\section{Результати}

Зоопланктон у водоймах Ічнянського національного природного парку представлений 81 видом. Моногононтні коловертки налічують 35 видів (43,2\% загальної кількості видів) і бделоїдні коловертки (підклас Bdelloidea). Гіллястовусі рако- подібні представлені 28 видами (34,6\%). Веслоногих ракоподібних зареєстровано 18 видів (22,2\%). Таким чином, у загальному видовому списку зоопланктону за фауністичним спектром угруповань переважали представники ротаторно-кладоцерного комплексу. Протягом 2015 року зібрано 55 видів зоопланктону. Коловертки складали 23 види, гіллястовусі ракопо- 
дібні - 17 та веслоногі ракоподібні - 15. Тоді як, у 2016 році зареєстровано 63 види, 3 яких коловерток -28 , гіллястовусих -22 і веслоногих ракоподібних - 13. Індекс Жаккара підтвердив невисоку подібність видового складу за різні роки: $\mathrm{J}=45,7 \%$. Видовий склад у межах Київського водосховища нараховував 193 види зоопланктону, 3 яких коловертки складали 110, гіллястовусі ракоподібні - 57 та веслоногі ракоподібні - 26 видів (табл. 1).

\section{Таблиця 1}

Видове багатство (\%) різнотипних водойм Ічнянського НПП

\begin{tabular}{llll}
\hline № & Види & 2015 & 2016 \\
\hline \multicolumn{3}{c}{ Клас Eurotatoria } \\
\hline
\end{tabular}

1 Anuraeopsis fissa fissa Gosse, 1851

2 Asplanchna priodonta Gosse, 1850

3 Brachionus angularis Gosse, 1851

4 Brachionus bennini Leissling, 1924

5 B. calyciflorus Pallas, 1766

6 B. diversicornis (Daday, 1883)

7 B. quadridentatus Hermann, 1783

8 B. urceolaris O. F. Müller, 1773

9 Colurella sp. Bory De St. Vincent, 1824

10 Dipleuchlanis propatula (Gosse, 1886)

11 Epiphanes senta (O. F. Müller, 1773)

12 E.sp.

13 Euchlanis deflexa (Gosse, 1851)

14 E. dilatata Ehrenberg, 1832

15 Filinia longiseta (Ehrenberg, 1834)

16 F. passa (O. F. Müller, 1786)

17 Keratella cochlearis (Gosse, 1851)

18 K. quadrata (O. F. Müller, 1786)

19 K. tropica (Apstein, 1907)

20 Lecane bulla (Gosse, 1851)

21 L. luna (O. F. Müller, 1776)

22 L. lunaris (Ehrenberg, 1832)

23 Lepadella patella (Gosse, 1886)

24 Monommata appendiculata Stenroos, 1898

25 Mytilina ventralis (Ehrenberg, 1830)

26 Notholca acuminata (Ehrenberg, 1832)

27 Platyias quadricornis (Ehrenberg, 1832)

28 Polyarthra dolicoptera Idelson, 1925

29 P. vulgaris Carlin, 1943

30 Scaridium longicaudum (O.F.Müller, 1786)

31 Synchaeta pectinata Ehrenberg, 1832

32 Testudinella patina (Hermann, 1783)

33 Trichocerca rattus (O.F.Müller, 1776)

34 Trichotria pocillum (O.F.Müller, 1776)

35 T. truncata (Whitelegge, 1889)

Bdelloidea Hudson, 1884

Кількість видів коловерток $(S)$ Клас Branchiopoda, ряд Cladocera

36 Acroperus harpae (Baird 1834)

37 Alona guttata Sars, 1862

38 A. quadrangularis (O. F. Müller, 1776)

39 A. rectangula Sars, 1862

40 Alonella excisa (Fischer, 1854)

41 A. nana (Baird 1843)

42 Bosmina longirostris (O.F.Müller, 1776)

43 Ceriodaphnia affinis Lilljeborg, 1900

44 C. pulchella Sars, 1862

45 Chydorus piger Sars, 1862

46 C. sphaericus (O.F.Müller, 1785)

47 Daphnia cucullata Sars, 1862

48 D. longispina (O. F. Müller, 1776)

49 D. pulex Leydig, 1860

50 Diaphanosoma brachyurum (Lievin, 1848)

51 Eurycercus lamellatus (O. F. Müller, 1776)

52 Graptoleberis testudinaria (Fischer, 1848)

53 Ilyocryptus agilis Kurz, 1878

54 Leydigia acanthocercoides (Fischer, 1854)

55 Macrothrix hirsuticornis Norman \& Brady, 1867

56 Moina rectirostris (Leydig, 1860)

57 Oxyurella tenuicaudis (Sars, 1862)

58 Picripleuroxus striatus Schödler, 1862

59 Pleuroxus aduncus (Jurine, 1820)

60 P. uncinatus Baird, 1850

61 Scapholeberis aurita (Fischer, 1849)

\begin{tabular}{|c|c|c|c|}
\hline № & Види & 2015 & 2016 \\
\hline 62 & S. mucronata (O. F. Müller, 1776) & 30 & 40 \\
\hline \multirow[t]{2}{*}{63} & Simocephalus vetulus (O. F. Müller, 1776) & 30 & 70 \\
\hline & Кількість видів гіллястовусих ракоподібних $(S)$ & 17 & 22 \\
\hline \multicolumn{4}{|c|}{ Клас Copepoda } \\
\hline 64 & Acanthocyclops americanus (Marsh, 1893) & 40 & 70 \\
\hline 65 & Cyclops strenuus Fischer, 1851 & - & 50 \\
\hline 66 & C. vicinus Ulianine, 1875 & 20 & - \\
\hline 67 & Diacyclops bicuspidatus (Claus, 1857) & 40 & 40 \\
\hline 68 & Ectocyclops phaleratus (Koch, 1838) & - & 10 \\
\hline 69 & Eucyclops denticulatus (Graeter, 1903) & 30 & 60 \\
\hline 70 & E. macrurus (Sars, 1863) & 10 & - \\
\hline 71 & E. serrulatus (Fischer, 1851) & 40 & 70 \\
\hline 72 & Macrocyclops albidus (Jurine, 1820) & 30 & 30 \\
\hline 73 & M. fuscus (Jurine, 1820) & 10 & - \\
\hline 74 & Megacyclops gigas (Claus, 1857) & 30 & - \\
\hline 75 & M. viridis (Jurine, 1820) & 40 & 50 \\
\hline 76 & Mesocyclops leuckarti (Claus, 1857) & 70 & 60 \\
\hline 77 & Thermocyclops crassus (Fischer, 1853) & 40 & 20 \\
\hline 78 & Th. oithonoides (Sars, 1863) & 60 & 40 \\
\hline 79 & Eudiaptomus gracilis (Sars, 1863) & 40 & 30 \\
\hline 80 & Eu. graciloides (Lilljeborg, 1888) & 20 & - \\
\hline \multirow[t]{3}{*}{81} & Eurytemora velox (Lilljeborg, 1853) & - & 10 \\
\hline & Кількість видів веслоногих ракоподібких $(S)$ & 15 & 13 \\
\hline & Кількість видів усіх груп зоопланктону $(S)$ & 55 & 63 \\
\hline
\end{tabular}

Приміти: Р - частота трапляння виду, або відсоток станцій, у межах яких зареєстровано даний вид, від загальної кількості обстежених станцій (Arsan et al., 2006).

Видове багатство зоопланктону віднесене до 3 класів, 5 рядів, 22 родини та 51 роду. Серед моногононтних коловерток відмічені представники двох рядів (Ploima, Flosculariaceae), 14 родин і 21 роду (табл. 2). Найвищими показниками видового складу характеризуються родина Brachionidae (12 видів), інші родини мають незначну кількість видів. Гіллястовусі ракоподібні належать до 5 родин і 19 родів, серед яких переважають за видовою представленістю родини Chydoridae та Daphniidae (15 і 8 видів відповідно). Веслоногі ракоподібні об'єднують два ряди (Calanoida, Cyclopoida), 3 родини та 11 родів, причому до родин Суclopidae належать 15 видів, Temoridae - 1 вид, Eudiaptomidae - 2 види.

За екологічним спектром у складі угруповань зоопланктону відмічено представників трьох екологічних груп: пелагічна, придонна та фітофільна. Екологічний спектр угруповання зоопланктону протягом двох років характеризувався значним переважанням пелагічної групи над придонною і фітофільною. Пелагічних видів виявлено 35 (43,2\%) від загальних 81, придонних - 20 (24,7\%), фітофільних - 26 (32,1\%). Коловертки переважали в межах пелагічної групи - 18 (51,4\%) видів із 35, а кладоцери у придонній групі - 10 (50\%) видів із 20. Загалом протягом обох років досліджень переважали представники пелагічної групи зоопланктону: 2015 рік - 26 (47,3\%) із 55, 2016 рік - 28 (44,4\%) із 63 (рис. 2). У межах Київського водосховища трофічний спектр характеризується переважанням фітофільної - 71 вид (37\%) і пелагічної груп - 69 (36\%) над придонною - 53 (27\%).

Види зоопланктону розрізняють також за типом живлення (трофічний спектр), відносячи його до складу трьох трофічних груп: мирні 64 (79\%) види із 81, всеїдні - $6(7,4 \%)$ та хижаки - 11 $(13,6 \%)$. Серед коловерток переважали мирні представники 34 (97\%) види, 1 вид (3\%) - всеїдний.

Гіллястовусі ракоподібні представлені мирною групою - 28 (100\%) видів, тоді як веслоногі налічують мирних - 2 (11,1\%), всеїдних - 5 (27,8\%), а хижих - 11 (61,1\%). Протягом двох років досліджень тенденція представленості різних трофічних груп не змінювалася: серед коловерток переважає мирна група i наявний лише один всеїдний вид Asplanchna priodonta, серед гіллястовусих ракоподібних наявні лише мирні види, а веслоногі ракоподібні характеризуються приналежністю до трьох трофічних груп - мирні, всеїдні та хижаки (рис. 3.). У межах Київського водосховища переважали також мирні представники - 158 (82,0\%) видів, всеїдні - 20 (10,3\%), а хижі - 15 (7,7\%). Iз метою вивчення динаміки змін угруповань зоопланктону 
протягом року в межах різнотипних водойм Ічнянського національного природного парку проводили сезонні дослідження. Навесні 2015 року видове багатство зоопланктону різнотипних водойм Ічнянського НПІП склало 33 види: коловерток 18 (54,6\%) видів, гіллястовусих ракоподібних - 4 (12,1\%), веслоногих -11 (33,3\%). Влітку в заростях різних формацій вищих водних рослин i на чистоводі виявили 31 вид зоопланктону: коловерток - 10 (32,3\%) видів, гіллястовусих ракоподібних - 12 (38,7\%), веслоногих ракоподібних - 9 (29,0\%). Восени зареєстровано 23 види зоопланктону, 3 яких коловерток 6 (26,1\%), гіллястовусих - 6 (26,1\%), веслоногих ракоподібних - 11 (47,8\%). Навесні 2016 року зареєстровано 31 вид зоопланктону: коловерток - 13 (42,0\%), гіллястовусих - 7 (22,5\%), веслоногих ракоподібних - 11 (35,5\%). Влітку виявлено 37 видів зоопланктону, з яких коловерток 14 (37,9\%) видів, гіллястовусих ракоподібних - 13 (35,1\%), веслоногих ракоподібних - 10 (27\%). Восени зібрано 45 видів: коловерток 19 (42,2\%), гіллястовусих ракоподібних - 17 (37,8\%), веслоногих ракоподібних - $9(20,0 \%)$.

\section{Таблиця 2}

Таксономічний склад зоопланктону різнотипних водойм Ічнянського НПП

\begin{tabular}{|c|c|c|c|}
\hline Класи & Ряди & Родини & Роди (кількість видів) \\
\hline \multirow{14}{*}{ Eurotatoria } & \multirow{12}{*}{ Ploima } & Trichocercidae & Trichocerca (1) \\
\hline & & Synchaetidae & $\begin{array}{l}\text { Synchaeta (1), } \\
\text { Polyarthra (2) }\end{array}$ \\
\hline & & Scaridiidae & Scaridium (1) \\
\hline & & Asplanchnidae & Asplanchna (1) \\
\hline & & Lecanidae & Lecane (3) \\
\hline & & Notommatidae & Monommata (1) \\
\hline & & Epiphanidae & Epiphanes (2) \\
\hline & & Lepadellidae & $\begin{array}{l}\text { Colurella (1), } \\
\text { Lepadella (1) }\end{array}$ \\
\hline & & Euchlanidae & $\begin{array}{l}\text { Dipleuchlanis (1), } \\
\text { Euchlanis (2) }\end{array}$ \\
\hline & & Brachionidae & $\begin{array}{l}\text { Brachionus (6), } \\
\text { Keratella (3), } \\
\text { Anuraeopsis (1), } \\
\text { Notholca (1), } \\
\text { Platyias (1) } \\
\end{array}$ \\
\hline & & Trichotriidae & Trichotria (2) \\
\hline & & Mytilinidae & Mytilina (1) \\
\hline & \multirow{2}{*}{ Flosculariaceae } & Testudinellidae & Testudinalla (1) \\
\hline & & Filinidae & Filinia (2) \\
\hline \multirow{5}{*}{ Branchiopoda } & \multirow{5}{*}{ Cladocera } & Sididae & Diaphanosoma (1) \\
\hline & & Daphniidae & $\begin{array}{l}\text { Daphnia (3), } \\
\text { Simocephalus (1), } \\
\text { Moina (1), } \\
\text { Ceriodaphnia (2), } \\
\text { Scapholeberis (2) }\end{array}$ \\
\hline & & Macrothricidae & $\begin{array}{l}\text { Macrothrix (1), } \\
\text { Ilyocryptus (1) }\end{array}$ \\
\hline & & Chydoridae & $\begin{array}{l}\text { Acroperus (1), } \\
\text { Graptoleberis (1), } \\
\text { Chydorus (2), } \\
\text { Eurycercus (1), } \\
\text { Leydigia (1), } \\
\text { Alona (3), } \\
\text { Alonella (2), } \\
\text { Oxyurella (1), } \\
\text { Picripleuroxus (1), } \\
\text { Pleuroxus (2) }\end{array}$ \\
\hline & & Bosminidae & Bosmina (1) \\
\hline \multirow[b]{3}{*}{ Copepoda } & \multirow{2}{*}{ Calanoida } & Eudiaptomidae & Eudiaptomus (2) \\
\hline & & Temoridae & Eurytemora (1) \\
\hline & Cyclopoida & Cyclopidae & $\begin{array}{l}\text { Macrocyclops (2), } \\
\text { Eucyclops (3), } \\
\text { Ectocyclops (1), } \\
\text { Cyclops (2), } \\
\text { Acanthocyclops (1), } \\
\text { Megacyclops (2), } \\
\text { Diacyclops (1), } \\
\text { Mesocyclops (1), } \\
\text { Thermocyclops (2) }\end{array}$ \\
\hline
\end{tabular}

У 2015 році кількісні показники зоопланктону річки Іченька «дуже низькі» та «низькі». Навесні середні значення щільності та біомаси по річці «низькі» - $19170 \pm 8810$ екз./ $\mathrm{M}^{3} \mathrm{i}$ $0,19 \pm 0,02$ г/ $\mathbf{m}^{3}$ (рис. 4). За кількісними показниками переважають веслоногі ракоподібні $11700 \pm 13136$ екз./м ${ }^{3}$ і $0,17 \pm$ 0,04 г/м ${ }^{3}$, значно їм поступаються коловертки (7 $360 \pm 4416$ екз./ $\mathrm{M}^{3}$ і $\left.0,002 \pm 0,0008 \Gamma / \mathrm{M}^{3}\right)$ і гіллястовусі ракоподібні $(110 \pm$

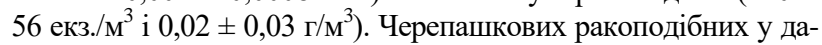
ний період року не відмічено. Влітку кількісні показники зоопланктону помітно відрізняються від весняних. Загальна щіль-

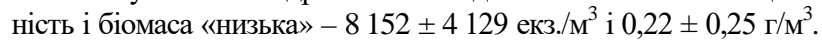
Як навесні, так і влітку за кількісними показниками домінують

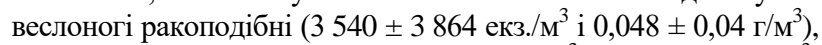

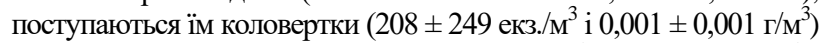

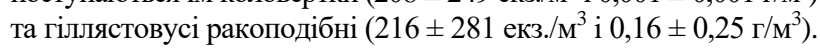
Незначні кількісні показники характерні черепашковим рако-

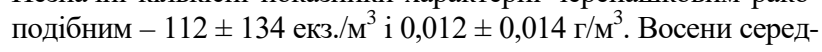
ня щільність та біомаса зоопланктону по річці «низька» -

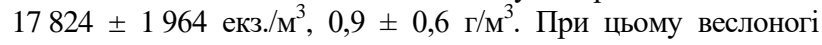
ракоподібні - домінантна група за щільністю (5 904 22860 екз. $\left./ \mathrm{M}^{3}\right)$ та біомасою $\left(0,84 \pm 0,5 \mathrm{\Gamma} / \mathrm{M}^{3}\right)$. Поступаються їм коло-

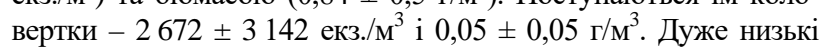
кількісні показники у гіллястовусих ракоподібних - $192 \pm$

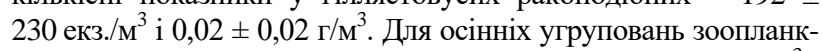
тону відмічені також черепашкові ракоподібні $\left(144 \pm 230\right.$ екз./м ${ }^{3}$ i $\left.0,01 \pm 0,01 \Gamma / \mathrm{m}^{3}\right)$. Переважання за кількісними показниками протягом року в річці веслоногих ракоподібних пов'язане 3 великою кількістю личинкових стадій копепод і їх високою індивідуальною масою.

Протягом 2016 року кількісні показники для річки «дуже низькі» та «низькі» (рис. 4). Навесні середні значення щільності «дуже низькі» - $3900 \pm 4800$ екз./ ${ }^{3}$ та біомаси $0,085 \pm$ 0,083 г/м ${ }^{3}$. За кількісними показниками переважають веслоногі

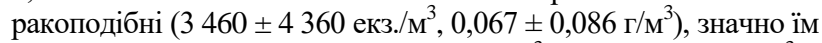

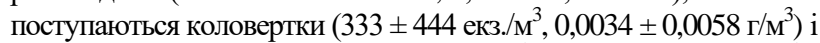

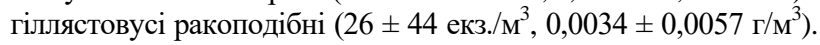
Незначні кількісні показники характерні черепашковим рако-

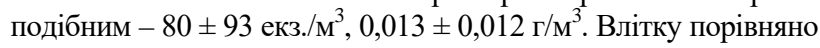
3 весною відмічено нижчі показники щільності $3660 \pm$

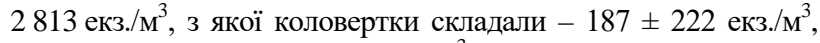
гіллястовусі - $1333 \pm 1982$ екз./м³, веслоногі - $1947 \pm 1662$ екз./м ${ }^{3}$ черепашкові ракоподібні - $193 \pm 267$ екз./м³. Тоді як для біомаси - вищі показники $\left(0,13 \pm 0,13 \Gamma / \mathrm{M}^{3}\right)$ : коловертки -

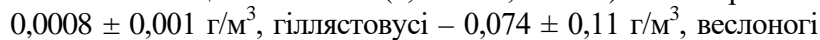
ракоподібні - 0,03 $\pm 0,02 \Gamma / \mathrm{M}^{3}$, черепашкові ракоподібні - 0,021 \pm 0,026 г/м ${ }^{3}$. Восени середні показники для щільності зоопланктону «низькі» - $5632 \pm 4470$ екз./м³ , для біомаси - «дуже низькі» - 0,1 $\pm 0,07$ г/м³. При цьому веслоногі ракоподібні - домінантна група за щільністю (4 $504 \pm 3820$ екз./ $\left.{ }^{3}\right)$ і біомасою $\left(0,07 \pm 0,05 \Gamma / \mathrm{M}^{3}\right)$. Дуже низькі кількісні показники в коловерток $\left(384 \pm 428\right.$ екз. $/ \mathrm{M}^{3}$ і $\left.0,0014 \pm 0,0016 \Gamma / \mathrm{M}^{3}\right)$ і гіллястовусих ракоподібних $\left(680 \pm 656\right.$ екз./ $\left.\mathrm{m}^{3}, 0,025 \pm 0,033 \Gamma / \mathrm{m}^{3}\right)$. Незначні кількісні показники характерні черепашковим ракоподібним $\left(64 \pm 76\right.$ екз./ $\mathrm{M}^{3}$ i $\left.0,008 \pm 0,009 \Gamma / \mathrm{M}^{3}\right)$.

У 2015 році кількісні показники зоопланктону ставків «дуже низькі» та «нижчі за середні» (рис. 5). Навесні середні значення щільності та біомаси зоопланктону «нижчі середніх» -

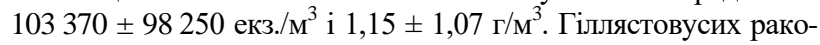
подібних у даний період року не відмічено. За кількісними показниками переважають веслоногі ракоподібні - $89470 \pm$

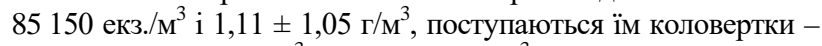

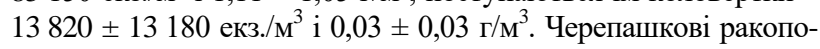
дібні характеризуються незначними кількісними показниками -

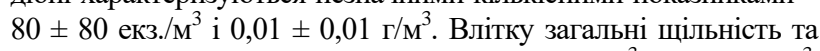

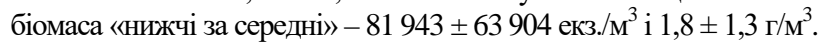
Порівняно з весняними даними, значно збільшилась кількісні

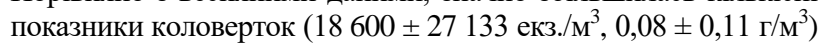
та гіллястовусих ракоподібних (18 $773 \pm 17284$ екз./ ${ }^{3}, 0,8 \pm$ $\left.0,8 \Gamma / \mathbf{M}^{3}\right)$. При цьому веслоногі ракоподібні - домінантна група 
за щільністю (44 $036 \pm 24442$ екз./ $\left.\mathrm{M}^{3}\right)$ та біомасою $\left(0,05 \pm 0,07\right.$ г $\left./ \mathrm{M}^{3}\right)$. Для літніх угруповань зоопланктону відмічені також черепашкові ракоподібні $\left(533 \pm 711\right.$ екз./ $\mathrm{m}^{3}$ і $0,05 \pm 0,07$ г/ $\left.\mathrm{M}^{3}\right)$. Восени середня щільність та біомаса по ставках «дуже низька» $-420 \pm$ 420 екз./ $\mathrm{M}^{3}$ і $0,05 \pm 0,05$ г/м ${ }^{3}$. Коловерток і черепашкових ракоподібних у даний період року не виявлено. За кількісними по- казниками переважають гіллястовусі ракоподібні $(300 \pm$ 300 екз. $/ \mathrm{m}^{3}$ і $\left.0,04 \pm 0,04 \mathrm{\Gamma} / \mathrm{m}^{3}\right)$, поступаються їм веслоногі

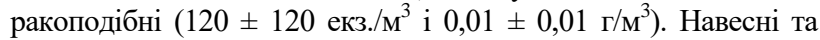
влітку переважав копеподний комплекс, восени - кладоцерний. Це можна пояснити низькою температурою у водоймах і гниттям вищої водної рослинності.

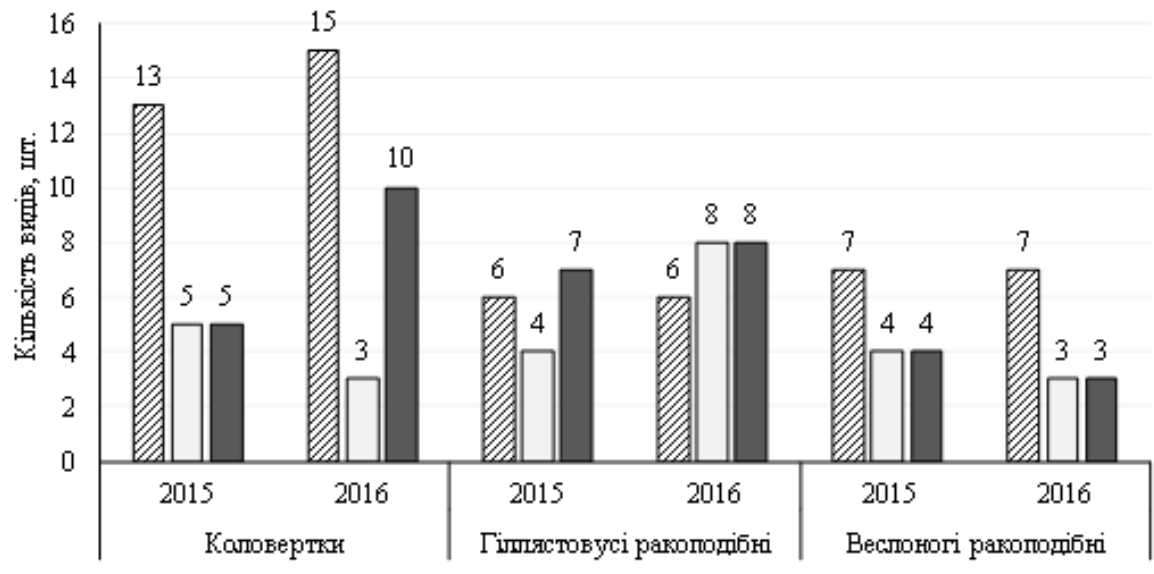

Групи зооптанктону

\section{चПЛ वПР चФ}

Рис. 2. Міжрічні зміни складу екологічного спектру зоопланктону в межах водойм Ічнянського національного природного парку: ПЛ - пелагічна група, ПР - придонна, Ф - фітофільна

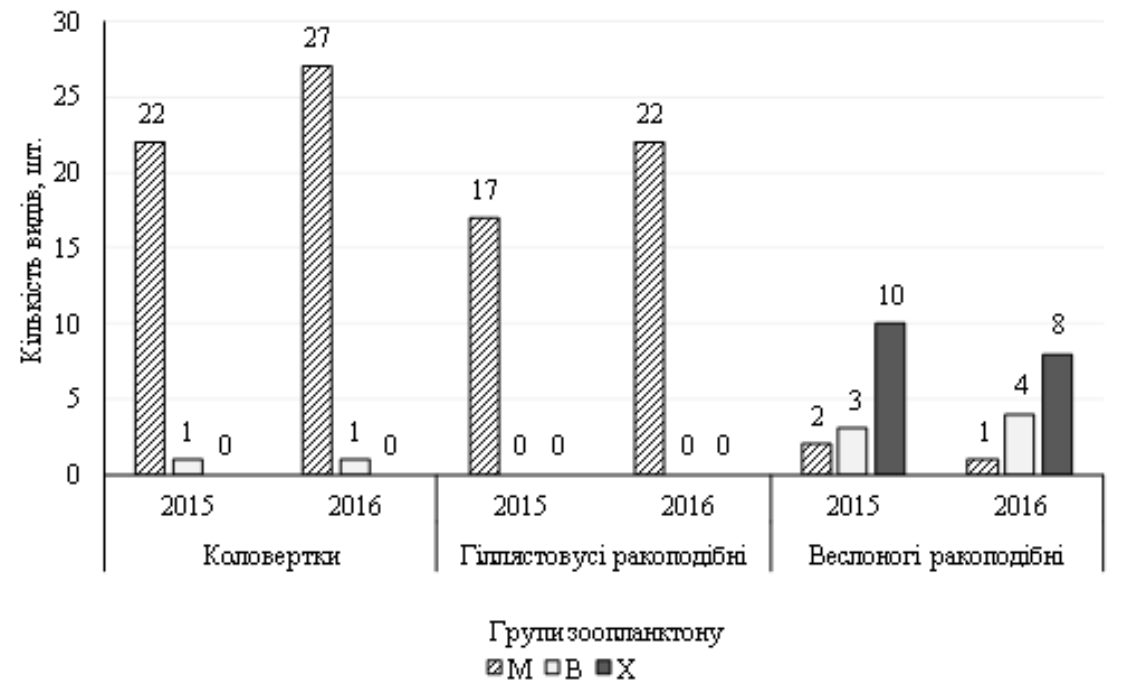

Рис. 3. Міжрічні зміни трофічного спектру основних груп зоопланктону водойм Ічнянського національного природного парку:

$$
\text { М - мирна група, В - всеїдні, X - хижаки }
$$

У 2016 році кількісні показники зоопланктону ставків «низькі» та «нижчі за середні» (рис. 5). Навесні середні показники щільності та біомаси «нижчі за середні» - $65931 \pm 51735$

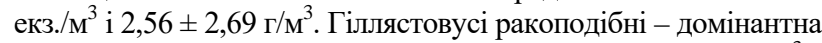
група за кількісними показниками - $32457 \pm 46138$ екз./ ${ }^{3} \mathrm{i}$ $1,87 \pm 2,66$ г/м ${ }^{3}$, значно їм поступаються коловертки (7929 \pm

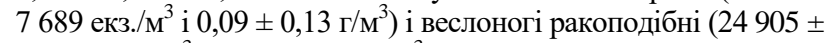
19776 екз. $/ \mathrm{m}^{3}$ і 0,53 $\left.\pm 0,42 \Gamma / \mathrm{m}^{3}\right)$. Дуже низькі кількісні показники у черепашкових ракоподібних $-640 \pm 720$ екз./ $\mathrm{M}^{3}$ і $0,064 \pm$ $0,072 \Gamma / \mathrm{m}^{3}$. Влітку кількісні показники «нижчі за середні»-

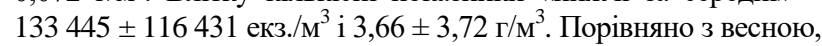
влітку за щільністю веслоногі ракоподібні - домінантна група $85491 \pm 111345$ екз. $/ \mathrm{M}^{3}$, поступаються їм коловертки (8 $002 \pm$

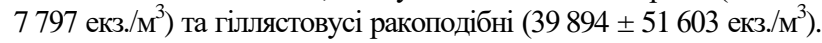
За біомасою переважали гіллястовусі ракоподібні - 2,28 \pm $3,11 \Gamma / \mathrm{M}^{3}$, коловертки складали $0,02 \pm 0,02 \Gamma / \mathrm{M}^{3}$, веслоногі $-1,35 \pm$ 1,5 г/м ${ }^{3}$. Черепашкові ракоподібні характеризуються низькими

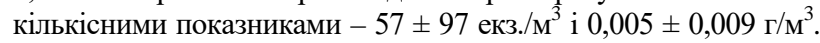
Восени середні показники щільності та біомаси по ставках

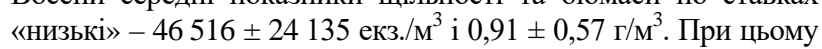

представники гіллястовусих переважали за щільнісю та біома-

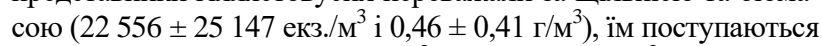

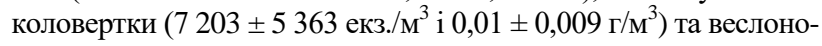
гі ракоподібні. Черепашкових ракоподібних у даний період року не відмічено.

У 2015 році кількісні показники зоопланктону боліт «дуже низькі», «низькі», «нижчі за середні» та «середні» (рис. 6). Навесні у болотах Ічнянського НПП проби зоопланктону не відбирали. Влітку середні показники щільності та біомаси зоопланктону «нижчі за середні» та «середні» - $14400 \pm 122800$ екз. $/ \mathrm{m}^{3}$ і $6,84 \pm 6,48$ г/м ${ }^{3}$. Веслоногі ракоподібні переважали за кількісними показниками $\left(144200 \pm 122800\right.$ екз./ ${ }^{3}$ i $6,81 \pm$ $6,40 \Gamma / \mathrm{m}^{3}$ ). Дуже низькі кількісні показники у гіллястовусих ракоподібних $-600 \pm 600$ екз./ $\mathrm{m}^{3}$ i $0,03 \pm 0,03$ г/м ${ }^{3}$. Коловерток i черепашкових ракоподібних у даний період року не відмічено. Восени більшість боліт пересохли. Середні кількісні показники «дуже низькі». При цьому веслоногі ракоподібні переважа-

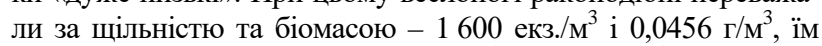

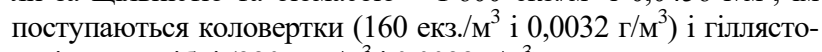

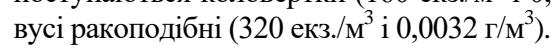



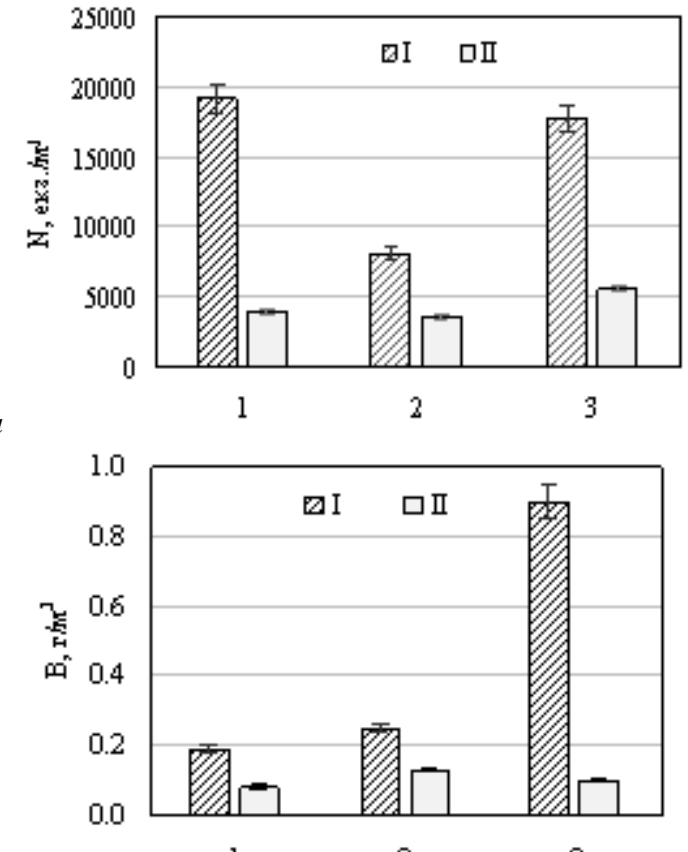

6

Рис. 4. Часові зміни щільності (a) та біомаси (б) зоопланктону річки Іченька: 1 - весна, 2 - літо, 3 - осінь; I - 2015 р., II - 2016 р.
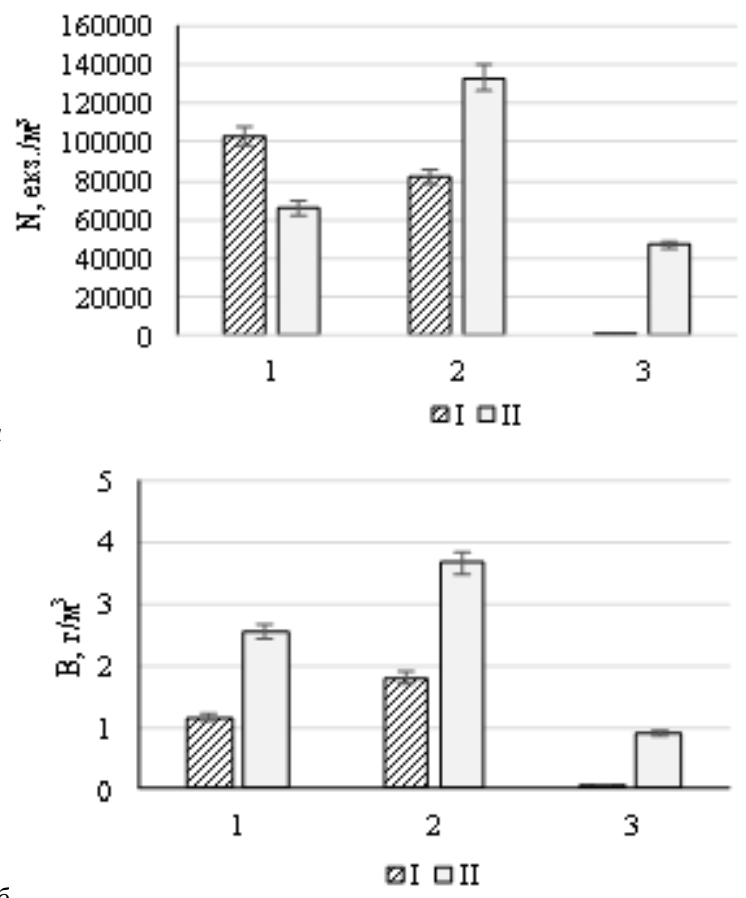

Рис. 5. Часові зміни щільності (a) та біомаси (б) зоопланктону ставків: 1 - весна, 2 - літо, 3 - осінь; I - 2015 р., II - 2016 р.

У 2016 році кількісні показники зоопланктону «низькі» та «нижчі за середні». Навесні середні значення щільності та біо-

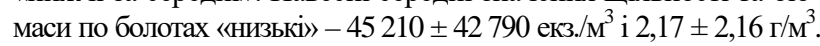
Веслоногі ракоподібні переважали за щільністю та біомасою -

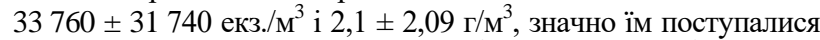

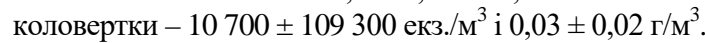

Дуже низькі кількісні показники у гіллястовусих ракопо-

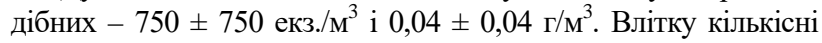
показники зоопланктону помітно відрізняються від весняних. Загальна щільність і біомаса «нижчі за середні» - $90400 \pm$ 56000 екз. $/ \mathrm{M}^{3}$ і $3,12 \pm 1,6$ г $/ \mathrm{M}^{3}$. За кількісними показниками до-

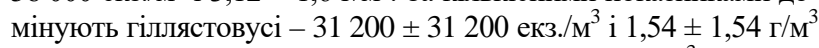

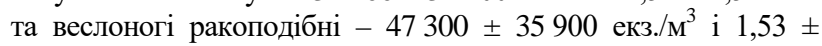

0,10 г/м ${ }^{3}$, їм поступаються коловертки - $11900 \pm 11100$ екз./ ${ }^{3}$ i $0,05 \pm 0,04 \Gamma / \mathrm{m}^{3}$. Восени, як і минулого року, більшість боліт пересохли. Середні кількісні показники зоопланктону на боло-

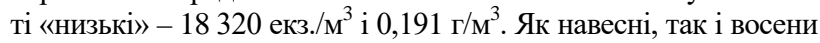
за щільністю та біомасою домінують веслоногі ракоподібні -

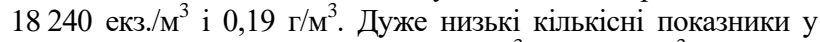

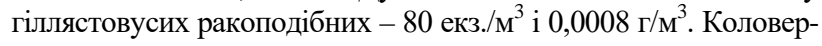
ток і черепашкових ракоподібних для даного сезону не зареєстровано.

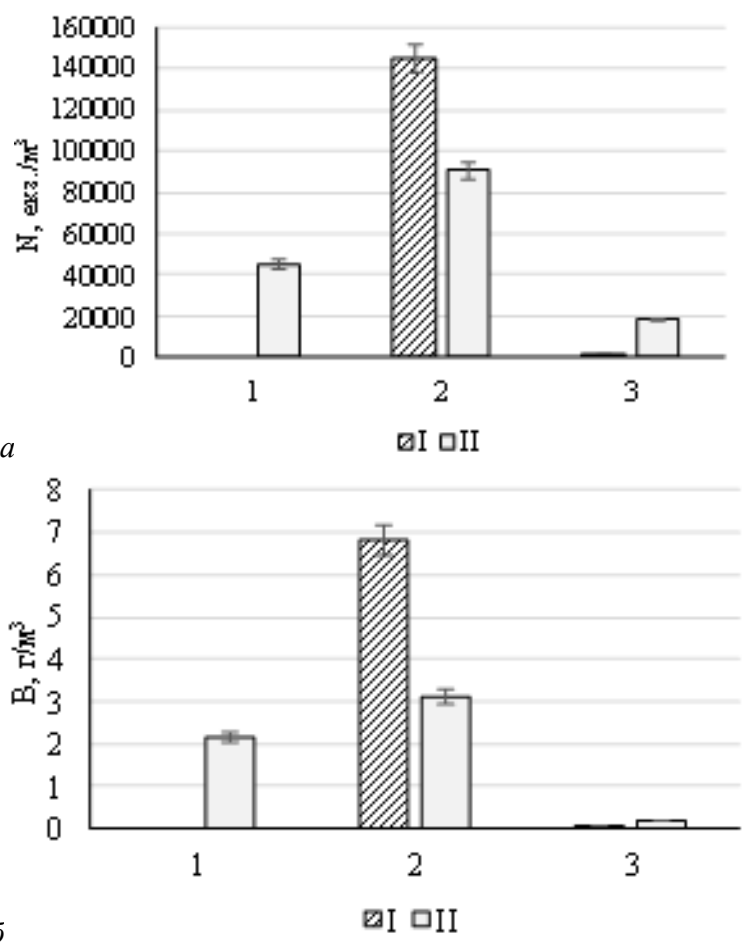

Рис. 6. Часові зміни щільності ( $a$ ) та біомаси (б) зоопланктону боліт: 1 - весна, 2 - літо, 3 - осінь; I - 2015 р., II - 2016 p.

У 2015 році кількісні показники зоопланктону тимчасової водойми «нижчі за середні», «вищі за середні», «високі». Для водойми протягом усіх сезонів характерний зарослий біотоп у формаціях - очерет звичайний, рогіз широколистий, ряска мала. Навесні середні кількісні показники «дуже високі» за щільністю - 3016000 екз./ $\mathrm{m}^{3}$ та «вищі за середні» за біомасою 19,4 г/м ${ }^{3}$ (рис. 7). Коловертки переважали за щільністю та біомасою - 299600 екз./ м $^{3}$ і 19,3 г/м ${ }^{3}$ із домінантним видом Brachionus calyciflorus, який складав 90\% (2716000 екз./ $\left.{ }^{3}\right)$ iз

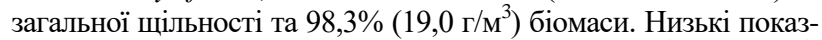
ники у веслоногих ракоподібних - 20000 екз./ $\mathrm{m}^{3}$ i $0,1 \mathrm{r} / \mathrm{m}^{3}$. Гіллястовусих і черепашкових ракоподібних у даному сезоні не виявлено. Влітку дуже різко зменшились кількісні показники, не відмічено коловерток і черепашкових ракоподібних. Середні показники щільності та біомаси «нижчі за середні» -

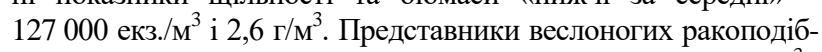
них переважали за кількісними показниками - 125600 екз./ ${ }^{3}$ i 2,5 г/м ${ }^{3}$. Дуже низька щільність і біомаса у гіллястовусих рако-

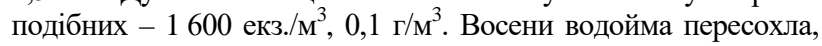
відповідно не було змоги відібрати матеріал.

У 2016 році кількісні показники зоопланктону тимчасової водойми «низькі» та «нижчі за середні».

Порівняно $з$ минулим роком, навесні 2016 р. (рис. 7) загальні кількісні показники «нижчі за середні» - 208600 екз./ ${ }^{3}$ i 3,22 г/м м $^{3}$ Відповідно, за кількісними показниками змінилася домінантна група 3 коловерток, які в цьому році навесні мали дуже низькі показники - 2000 екз. $/ \mathrm{M}^{3}$ і $0,008 \mathrm{\Gamma} / \mathrm{m}^{3}$, на весло-

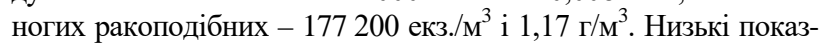
ники щільності та біомаси характерні для гіллястовусих рако-

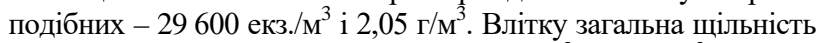

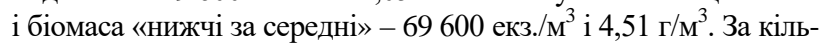


кісними показниками переважають гіллястовусі ракоподібні 66000 екз. $/ \mathrm{M}^{3}$ i $4,22 \mathrm{\Gamma} / \mathrm{m}^{3}$, із чітко вираженим домінантним видом - Daphnia pulex, який складає значну частку - 88,5\%

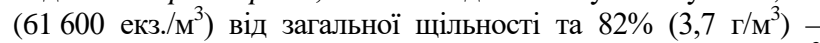
біомаси; їм поступаються веслоногі ракоподібні - 3200 екз./м ${ }^{3}$ i $0,25 \Gamma / \mathrm{m}^{3}$. Незначні показники зареєстровані для черепашко-

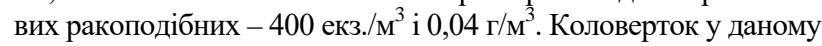
сезоні не відмічено. Восени показники для тимчасової водой-

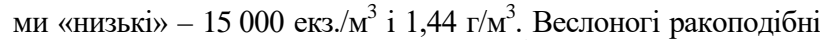
переважали за щільністю - 6600 екз./ $\mathrm{M}^{3}$, значно їм поступалися коловертки (200 екз./ $\left.\mathrm{M}^{3}\right)$ та гіллястовусі ракоподібні (4 200 екз./M ${ }^{3}$ ), за біомасою домінували представники гіллястовусих ракоподібних $-0,66$ г/ $\mathrm{m}^{3}$, їм поступалися веслоногі ракоподібні - 0,38 $\mathrm{r} / \mathrm{M}^{3}$. Дуже низькі показники біомаси в коловерток $-0,004 \Gamma / \mathbf{m}^{3}$. Для осінніх угруповань зоопланктону відмі-

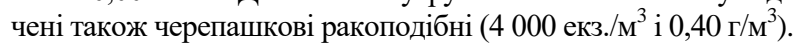

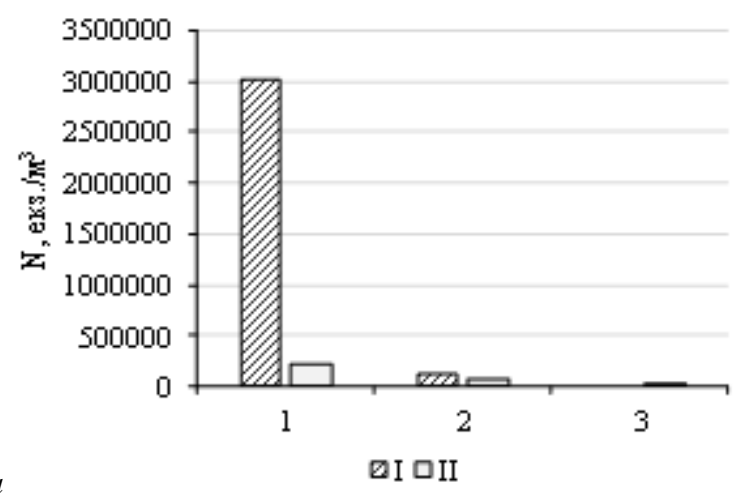

$a$

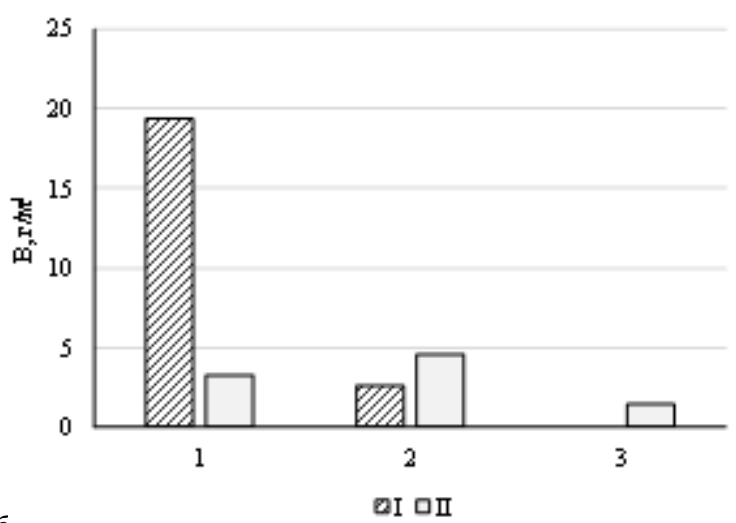

Рис. 7. Часові щільності (a) та біомаси (б) зоопланктону тимчасової водойми: 1 - весна, 2 - літо, 3 - осінь; I - 2015 р., II - 2016 р.

У межах Київського водосховища навесні зоопланктон має «дуже низькі», «низькі» та «нижчі за середні» показники. Загалом же його щільність варіює в межах 600-213000 екз./ м $^{3}$, а біомаса $-<0,01-1,01 \Gamma / \mathbf{m}^{3}$. Влітку літоральний зоопланктон удень має «дуже низькі», «низькі», «нижчі за середні», «середні» та «вищі за середні» показники. Його щільність варіює в

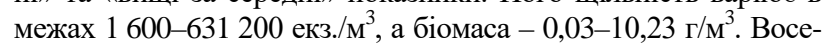
ни літоральний зоопланктон характеризується «дуже низькими», «низькими» та «нижчими за середні» показниками. Його щільність варіює в межах $<100-73400$ екз./ м $^{3}$, а біомаса $<0,01-4,88 \Gamma / \mathrm{M}^{3}$.

\section{Обговорення}

Аналізуючи отримані нами дані варто зазначити, що більшість із 81 зареєстрованого виду фауни Ічнянського національного природного парку притаманні й для фауни національних парків європейської частини (Ortega-Mayagoitia et al., 2000; Güher et al., 2011). Наприклад, для водойм національного парку Лас Таблас де-Дайм'єль (Іспанія) зареєстровано 91 вид зоопланктону. У той же час, що в наших дослідженнях, що у євро- пейський, відбувається домінування популяції коловерток за якісними показниками (Ortega-Mayagoitia et al., 2000). Це може бути пов'язане з особливостями поширення даного виду в різнотипних водоймах із низькими температурами та слабким розвитком макрофітів. Високе видове багатство Київського водосховища, порівняно з різнотипними водоймами Ічнянського НПП, можна пояснити більш розвиненими таксономічною та екологічною структурами угруповань зоопланктону. Тому в межах водосховища спостерігається олігодомінантність або полідомінантність угруповань зоопланктону, а для дрібних водойм національного парку - монодомінантність або олігодомінантність.

Окремо варто підкреслити значення вищих рослин у формуванні видового багатства коловерток. У межах дослідних водойм виявлено різні угрупування вищих водних рослин, серед яких переважають представники ротаторного комплексу зоопланктону. Якщо основу асоціації макрофітів формує очерет звичайний, то простежується тенденція до зниження видового складу коловерток, у той час як у ракоподібних видове багатство зростає. За впливом інших формацій вищих водних рослин на видовий склад коловерток кореляції не виявлено.

Фауністичний спектр зоопланктону протягом різних років i сезонів характеризується переважанням ротаторного комплексу навесні, ротаторно-кладоцерного та кладоцерного влітку та копеподного восени. Згідно класичних уявлень такий розподіл пов'язують із формуванням протягом весни та літа сприятливих гідробіологічних умов для фільтраторів, серед яких значну частину складають коловертки та гіллястовусі ракоподібні. Крім того варто зазначити, що збільшення кількості органічних речовин, які потрапляють у воду в осінній період, у свою чергу може вести до зниження видового багатства коловерток.

У ході аналізу екологічного спектру угрупувань зоопланктону виявлено домінування представників пелагічної групи 35 видів (43,2\%). Таке переважання пелагічних видів зазвичай пов'язане 3 мілководністю водойми, а також наявністю щільних формацій вищих водних рослин (очерет звичайний, рогіз широколистий, глечики жовті тощо). Загалом угруповання зоопланктону Київського водосховища характеризується переважанням фітофільної групи - 71 вид (37,0\%).

Класичним, для даних типів водойм, виявився трофічний спектр зоопланктону, представлений зоопланктерами трьох трофічних груп. Найбільший відсоток мирних представників складали коловертки та гіллястовусі ракоподібні, серед всеїдних та хижаків - веслоногі ракоподібні (рис. 3). Протягом двох років проведення досліджень тенденція представленості різних трофічних груп не змінювалася. Загальний аналіз типу живлення представників зоопланктону різнотипних водойм Ічнянського національного парку та зоопланктону Київського водосховища, вказує на переважання у водоймах різних типів видів мирної групи.

Кількісні показники (Arsan et al., 2006) зоопланктону p. Іченька протягом обох років дослідження, реєструвалися як «дуже низькі» та «низькі», що корелює 3 низьким видовим складом. Варто зазначити також що, річка живиться переважно атмосферними опадами 3 нерівномірним сезонним наповненням водойм (навесні притоки наповнюють, а влітку міліють), а також помірними підземними водами, крім того температурний режим досить низьким (весною $-+6 \ldots+7{ }^{\circ} \mathrm{C}$, влітку $-+18 \ldots+19{ }^{\circ} \mathrm{C}$, восени $\left.-+9 \ldots+10^{\circ} \mathrm{C}\right)$. Враховуючи ці умови для кладоцер і копепод виявились характерними низькі кількісні показники.

У той же час, кількісні показники зоопланктону в межах ставків помітно відрізнялись від річки - «дуже низькі», «низькі», «нижчі за середні» та «середні». Протягом обох років переважали за щільністю та біомасою представники гіллястовусих і веслоногих ракоподібних. Для боліт Ічнянського НПП прослідковувалась така ж тенденція за кількісними показниками - «дуже низькі», «низькі», «нижчі за середні» та «середні» (Ortega-Mayagoitia et al., 2000).

Кількісні показники зоопланктону тимчасової водойми найвищі порівняно з іншими водоймами та різняться в десятки разів (рис. 7). Все це може свідчити про нестійкість угруповання. 
У межах Київського водосховища зоопланктон має «дуже низькі», «низькі» та «нижчі за середні», «вищі за середні» кількісні показники. Низькі кількісні показники - норма для великих стабільних водойм. Тоді як стави, болота та тимчасові водойми мають високі кількісні показними та низьке видове багатство.

\section{Висновки}

Протягом двох років досліджень угруповань зоопланктону, які проводили вперше для Ічнянськто НПП, зареєстровано 81 вид зоопланктону: коловертки - 35 (43,2\%), гіллястовусі ракоподібні $28(34,6 \%)$, веслоногі ракоподібні - 18 вид (22,2\%). За фауністичним спектром угруповання зоопланктону переважає ротаторнокладоцерний комплекс. Протягом 2015 року зібрано 55 видів 30опланктону: коловерток - 23 види, гіллястовусих ракоподібних 17, веслоногих ракоподібних - 15. У 2016 році зареєстровано 63 види, 3 яких коловерток - 28, гіллястовусих -22 , веслоногих ракоподібних - 13. Порівняльний аналіз видового складу угруповань зоопланктону за різні роки показав їх невисоку подібність $(\mathrm{J}=45,7 \%)$. За екологічним спектром угруповань зоопланктону домінує пелагічна група (43,2\%). За типом живлення найбільше зареєстровано представників мирної групи - 64 види (79\%) від загальних 81. Провівши сезонні дослідження виявлено, що весною за фауністичним спектром переважав ротаторний комплекс, влітку - ротаторно-кладоцерний і кладоцерний, а восени - ротаторнокладоцерний і копеподний. Восени 2016 року зареєстровано найбільшу за два роки кількість видів - 45. Щільність та біомаса зоопланктону в межах більшості дослідний станцій характеризувалася «дуже низькими» (менше 5000 екз./ $\mathrm{m}^{3}$ і менше $0,3 \mathrm{r} / \mathrm{m}^{3}$ ), «низькими» (5 000-50 000 екз./ $\mathrm{M}^{3}$ i $0,3-1,0$ г/M $\left.\mathrm{M}^{3}\right)$, «нижче середніх»

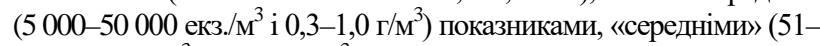
250000 екз. $\left./ \mathrm{M}^{3} \mathrm{i} 1,1-5,0 \mathrm{r} / \mathrm{M}^{3}\right)$, «вищі за середні» (501 000-1 000000

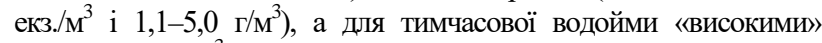
(3 016000 екз./ $\mathrm{M}^{3}$ ). Під час порівняння зоопланктону різнотипних водойм Ічнянського НПП із Київським водосховищем виявлено, що видове багатство зоопланктону нижче.

\section{References}

Arsan, O. M. (ed.) (2006). Metody gidroekologichnyh doslidzhen' poverhnevyh vod [Methods of hydroecological investigations of surface water]. Logos, Kyiv (in Ukrainian).

Baranyi, C., Hein, T., Holarek, C., Keckeis, F., \& Schiemer, F. (2002). Zooplankton biomass and community structure in a Danube River floodplain system. Freshwater Biology, 47(3), 473-482.

Berezina, N. A. (1989). Praktikum po gidrobiologii [Workshop on Hydrobiology]. Agropromizdat, Moscow (in Russian).

Bobyliov, Y. P., Brygadyrenko, V. V., Bulakhov, V. L., Gaichenko, V. A., Gasso, V. Y., Didukh, Y. P., Ivashov, A. V., Kucheriavyi, V. P., Maliovanyi, M. S., Mytsyk, L. P., Pakhomov, O. Y., Tsaryk, I. V., Shabanov, D. A. (2014). Ekologija [Ecology]. Folio, Kharkiv (in Ukrainian).

Booker, J., \& Cheruvelil, K. S. (2011). Are zooplankton food resources poorin the vegetated littoral zone of shallow lakes? Freshwater Biology, 51(12), 2459-2472.

Boruckij, E. V., Stepanova, L. A., \& Kos, S. (1991). Opredelitel' Calanoida presnyh vod SSSR [Determinant of Calanoida of fresh waters of USSR]. Nauka, Leningrad (in Russian).

Chalkia, E., \& Kehayias, G. (2013). Zooplankton and environmental factors of a recovering eutrophic lake (Lysimachia Lake, Western Greece). Biologia, 68(3), 459-469.

Czerniawski, R., \& Domagał, J. (2013). Reduction of zooplankton communities in small lake outlets in relation to abiotic and biotic factors. Oceanological and Hydrobiological Studies, 42(2), 123-131.

De los Ríos-Escalante, P. R. (2010). The ecology of the crustacean zooplankton in central and Southern Patagonian shallow ponds. Crustacean Zooplankton Communities in Chilean Inland Waters, 12, 79-90.
Dulić, Z., Mitrović-Tutundžić, V., Marcović, Z., \& Živić, I. (2006). Monitoring water quality using zooplankton organisms as bioindicators at the Dubica fish farm, Serbia. Archives of Biological Sciences, 58(4), 245-248.

Forró, I., Korovchinsky, N. M., Kotov, A. A., \& Petusek, A. (2008). Global diversity of cladocerans (Cladocera; Crustacea). Hydrobiologia, 595, 177-184.

Gophe, M. (2015). Ecophysiology of Lake Kinneret (Israel) zooplankton. Open Journal of Ecology, 5(5), 187-198.

Guevara, G., Lozano, P., Reinoso, G., \& Villa, F. (2009). Horizontal and seasonal patterns of tropical zooplankton from the eutrophic Prado Reservoir (Colombia). Limnologica - Ecology and Management of Inland Waters, 39(2), 128-139.

Güher, H., Erdoğan, S., Kırgız, T., \& Çamur-Elipek, B. (2011). The Dynamics of zooplankton in National Park of Lake Gala (Edime-Turkey). Acta Zoologia Bulgarica, 63(2), 157-168.

Havel, J. E., \& Shurin, J. B. (2004). Mechanisms, effects, and scales of dispersal in freshwater zooplankton. Limnology and Oceanography, 49(4), 1229-1238.

Lance, C. R., \& Bennett, D. H. (2003). Seasonal zooplankton abundance and size fluctuations across spatial scales in Lake Pend Oreille, Idaho. Freshwater Ecology, 17(2), 277-290.

Larson, G. L., Hoffman, R., McIntire, C. D., Lienkaemper, G., \& Samora, B. (2008). Zooplankton assemblages in montane lakes and ponds of Mount Rainier National Park, Washington State, USA. Journal of Plankton Research, 31(3), 273-285.

Manujlova, E. F. (1964). Vetvistousye rachki (Cladocera) fauny SSSR [Cladocerans (Cladocera) fauna of the USSR]. Nauka, Moscow, Leningrad (in Russian).

Martin, J. W., \& Davis, G. E. (2001). An updated classification of the recent Crustacea. Natural History Museum of Los Angeles Country, Los Angeles.

Meerhoff, M., Iglesias, C., Mello, F. T., Clemente, J. M., Jensen, E., Lauridsen, T. L. \& Jeppesen, E. (2007). Effects of habitat complexity on community structure and predator avoidance behaviour of littoral zooplankton in temperate versus subtropical shallow lakes. Freshwater Biology, 52(6), 1009-1021.

Monchenko, V. I. (2003). Vol'nozhivushhie ciklopovidnye kopepody PontoKaspijs'kogo bassejna [Free-living cyclopoid copepods of PontoKaspian basin]. Naukova Dumka, Kyiv (in Russian).

Nazaruk, K. M., \& Khamar, I. S. (2011). Zooplankton of some Lakes of the Shatsk National Natural Park. Hydrobiological Journal, 47(6), 33-44.

Ortega-Mayagoitia, E., Armengol, X., \& Rojo, C. (2000). Structure and dynamics of zooplankton in a semi-arid wetland, the National Park Las Tablas de Daimiel (Spain). Wetlands, 20(4), 629-638.

Pandey, A., \& Upadhyay, H. C. (2015). Studies on zooplankton diversity of Western Ramganga River in Almora (Uttarakhand) India. International Journal of Science and Research, 5(5), 1192-1194.

Pashkova, O. V. (2013). Zooplankton as indicator of organic and toxic pollution and ecological state of aquatic ecosystems (A review). Hydrobiological Journal, 49(2), 3-20.

Pesenko, J. A. (1982). Principy i metody kolichestvennogo analiza v faunisticheskih issledovanijah [Principles and methods of quantitative analysis in the faunal studies]. Nauka, Moscow (in Russian).

Segers, H. (2007). Annotated checklist of the rotifers (Phylum Rotifera), with notes on nomenclature, taxonomy and distribution. Magnolia Press, New Zealand.

Segers, H. (2008). Global diversity of rotifers (Rotifera) in freshwater. Hydrobiologia, 595, 49-59.

Sollberger, P. J., Paulson, L. J., \& Sollberger, P. J. (1992). Littoral and limnetic zooplankton communities in Lake Mead, Nevada-Arisona, USA. Hydrobiologia, 237(3), 175-184.

Soto, D., \& Rios, P. (2006). Influence of trophic status and conductivity on zooplankton composition in lakes and ponds of Torres del Paine National Park (Chile). Biologia, 61(5), 541-546.

Trokhymets, V. N., Sydorenko, M. V., \& Podobaylo, A. V. (2011). The Uday river's littoral zooplankton in the region of the national nature park «Pyriatynskiy». Visnyk of Dnipropetrovsk University. Biology, Ecology, 20(1), 131-138.

Uttah, E. C., Uttah, C., Akpa, P. A., Ikpeme, E. M., Ogbeche, J., Usip, L., \& Asor, J. (2010). Bio-survey of plankton as indicators of water quality for recreational activities in Calabar River, Nigeria. Journal of Applied Sciences and Environmental Management, 12(2), 35-42.

Xu, F. L, Tao, S., Dawson, R. W., Li, P., \& Cao, J. (2001). Lake ecosystems health assessment: Indicators and methods. Water Research, 12(2), 3157-3167.

Zhadin, V. N. (1960). Metody gidrobiologicheskogo issledovanija [Methods of hydrobiological studies]. Vysshaja Shkola, Moscow (in Russian). 